\title{
PENGARUH DPK, NPL, LDR DAN SUKU BUNGA KREDIT TERHADAP PENYALURAN KREDIT UMKM (STUDI PADA BPR DI KOTA SEMARANG TAHUN 2013-2016)
}

\author{
Farida Qusnul Khotimah \\ Program Studi Akuntansi STIE BANK BPD JATENG \\ Faridakhotimah89@gmail.com \\ Suci Atiningsih \\ atiningsih.suci@gmail.com
}

\begin{abstract}
The study aims to determine the effect of third-party Funds (DPK)), Non Performing Loan (NPL), Loan to Deposit Ratio (LDR), and Loan Interest Rates to UMKM lending. This research is quantitative by using secondary data. The population in this study ias all Rural Banks (BPR) in Semarang City registered in the Financial Services Authority (OJK) for the period of 2013-2016. By using purposive sampling method, obtained a sample of 64 banks. This research use analysis tool that is doubled linear regression. The variables in this study consist of four independent variabels which include third-party Funds (DPK), Non Performing Loan (NPL), Loan to Deposit Ratio (LDR), Loan Interest Rate and one dependent variable UMKM credit distribution. Based on the results found that the DPK has a positive and significant impact on the credit distribution of UMKM, the NPL has no negative and significant impact on the lending of UMKM, the LDR has a positive and significant impact on the credit distribution of UMKM, and the Interest Rates has no negative and significant impact on the lending of UMKM.
\end{abstract}

Key Words : third-party Funds (DPK), Non Performing Loan (NPL), Loan to Deposit Ratio (LDR), Loan Interest Rates, Credit Distribution UMKM.

\begin{abstract}
ABSTRAK
Penelitian ini bertujuan untuk mengetahui pengaruh Dana Pihak Ketiga (DPK), Non Performing Loan (NPL), Loan to Deposit Ratio (LDR) dan Suku Bunga Kredit untuk pinjaman UMKM. Penelitian ini bersifat kuantitatif dengan menggunakan data sekunder. Populasi dalam penelitian ini adalah seluruh BPR di Kota Semarang yang terdaftar di Otoritas Jasa Keuangan (OJK) untuk periode 2013-2016. Dengan menggunakan metode purposive sampling, diperoleh sampel sebanyak 64 bank. Penelitian ini menggunakan alat analisis yaitu regresi linier berganda. Variabel dalam penelitian ini terdiri dari empat variabel independen yang meliputi Dana Pihak Ketiga (DPK), Non Performing Loan (NPL), Loan to Deposit Ratio (LDR), Suku Bunga Kredit dan satu variabel dependen distribusi kredit UMKM. Berdasarkan hasil penelitian ditemukan bahwa DPK memiliki pengaruh positif dan signifikan terhadap penyaluran kredit UMKM, NPL tidak berdampak negatif dan signifikan terhadap pemberian kredit UMKM, LDR memiliki pengaruh positif dan signifikan terhadap penyaluran kredit UMKM, dan Tingkat Bunga tidak berdampak negatif dan signifikan terhadap pinjaman UMKM.
\end{abstract}

Kata Kunci: Dana Pihak Ketiga (DPK), Non Performing Loan (NPL), Loan to Deposit Ratio (LDR), Suku Bunga Kredit, Distribusi Kredit UMKM. 


\section{Pendahuluan}

Krisis keuangan global mempengaruhi kondisi perbankan di Indonesia, dampak krisis keuangan yang terjadi menyebabkan terganggunya kinerja keuangan perbankan. Setelah krisis yang terjadi di tahun 2008 sebenarnya menunjukkan kondisi perekonomian mulai mengalami perbaikan (Purba dkk, 2016). Pertumbuhan ekonomi yang signifikan dapat di lihat dari peningkatan investasi baik dari dalam maupun dari luar negeri, penurunan angka pengangguran dan meningkatnya pendapatan perkapita masyarakat. Dalam upaya peningkatan pertumbuhan ekonomi nasional pemerintah senantiasa menciptakan suasana ekonomi yang kondusif dengan memberikan mereka kemudahankemudahan bagi masyarakat dalam mengembangkan bisnisnya (Kaunang, 2013).

Ketahanan perekonomian Indonesia dari pengaruh krisis ekonomi global tidak terlepas dari peran usaha mikro kecil dan menengah (UMKM) karena sumber bahan baku lebih mengandalkan dari sumber domestik serta berasal dari pasar domestik (Purba dkk, 2013). Untuk itu, menurut Kementrian Koperasi dan UKM (2013) pemerintah pun menetapkan tiga tujuan dasar yakni:

1. Menumbuhkan kesadaran akan orientasi kewirausahaan yang kuat.

2. Meningkatkan jumlah orientasi kewirausahaan yang berkualitas.

3. Mewujudkan kemampuan bersaing para wirausahawan yang dapat menghasilkan kemajuan serta kesadaran masyarakat khususnya kepada para pemilik Usaha Mikro Kecil \& Menengah (UMKM).

Untuk mencapai tujuan tersebut, diperlukan bank khusus yang dapat melayani kebutuhan pelaku UMKM yang mampu membantu kondisi perkonomian masyarakat dalam memenuhi kebutuhan hidup. Dunia usaha yang berada di daerah pedesaan, seperti petani, peternak, nelayan, pedagang, pengrajin, serta pengusaha kecil lainnya, pada umumnya memerlukan kredit dalam jumlah yang terbatas. Kebutuhan masyarakat yang mendesak seringkali membuat kesulitan dalam penyediaan dana. Diperlukan bank khusus yang dapat melayani kebutuhan modal dengan prosedur pemberian kredit yang relatif mudah dan sesederhana mungkin (Purba dkk, 2016).

UMKM (Usaha Mikro, Kecil, dan Menengah) adalah suatu kelompok usaha yang dimana sering menggunakan sumber dayanya dari sektor pertanian, perkebunan, peternakan, dan perdagangan. UMKM ini merupakan kelompok usaha yang memiliki keunggulan dalam sisi penyerapan tenaga kerjanya yang banyak, sehingga dapat 
membantu proses pemerataan yang merupakan bagian dari pembangunan ekonomi negara (Anggraini dan Hakim, 2013).

Pemerintah Indonesia sendiri telah melakukan berbagai usaha dalam memajukan perekonomian Indonesia, salah satunya adalah dengan cara meningkatkan kinerja UMKM. Seperti instruksi Presiden Republik Indonesia Nomor 6 Tahun 2007 tentang kebijakan percepatan pengembangan sektor riil dan pemberdayaan usaha mikro, kecil dan menegah. Hal tersebut disebabkan sejalan dengan perkembangan jumlah UMKM di Indonesia yang terus meningkat dari tahun ketahun, sehinggga pemerintah melihat adanya kesempatan dan potensi yang baik dalam memaksimalkan sektor UMKM ini. Selain itu, pemerintah memiliki proyek lain berupa paket kebijakan yang memiliki tujuan untuk meningkatkan sektor riil dengan cara memberdayakan UMKM guna menciptakan lapangan pekerjaan dan penanggulangan kemiskinan. Kebijakan pengembangan dan pemberdayaan UMKM tersebut mencakup peningkatan akses pada sumber pembiayaan, pengembangan kewirausahaan, peningkatan pasar produk UMKM, dan reformasi regulasi UMKM (Komite KUR, 2012).

Sebagai lembaga intermediasi antara pihak-pihak yang memiliki dana berlebih dengan pihak-pihak yang memerlukan dana, agar fungsi intermediasinya dapat berjalan dengan baik maka dibutuhkan bank yang memiliki kinerja keuangan yang baik. Berdasarkan UU Nomor 10 tahun 1992 tentang perbankan sebagaimana telah diubah dengan UU Nomor 10 Tahun 1998, bank adalah badan usaha yang menghimpun dana dari masyarakat dalam bentuk simpanan dan menyalurkannya kembali kepada masyarakat dalam bentuk kredit dan atau bentuk-bentuk lainnya dalam rangka meningkatkan taraf hidup rakyat banyak.

Berdasarkan jenisnya bank ada 2 yaitu Bank Umum dan Bank Perkreditan Rakyat (BPR). Kedua jenis bank ini sama-sama dalam menjalankan fungsinya dan kegiatannya, yang membedakan adalah BPR dalam kegiatannya tidak melakukan jasa dalam lalu lintas pembayaran dan tidak menerima simpanan berupa giro (Paleni dan Aurora, 2016)..

Bank Perkreditan Rakyat (BPR) menempati peran yang cukup strategis dalam perekonomian Indonesia terutama dalam UMKM. Salah satu kunci sukses BPR dalam memberikan pelayanan adalah lokasi BPR yang dekat dengan masyarakat, prosedur yang sederhana, mengutamakan pendekatan personal, serta fleksibel dalam hal pola dan model pinjaman (Purba dkk, 2016). 
Menurut UU No. 10 Tahun 1998 kredit adalah penyediaan uang atau tagihan yang dapat dipersamakan dengan itu. Penyaluran kredit sebagai bentuk usaha bank mutlak dilakukan karena fungsi bank itu sendiri sebagai lembaga intermediasi yang mempertemukan kepentingan antara pihak-pihak yang kelebihan dana dengan pihak yang kekurangan dana. Tujuan utama pemberian kredit antara lain adalah mencari keuntungan, membantu usaha nasabah, dan membantu pemerintah (Kasmir, 2008). Oleh karena itu penyaluran kredit sangat membantu kegiatan perekonomian masyarakat yang membutuhkan dana dan akan menghasilkan keuntungan bagi bank dalam bentuk pendapatan bunga kredit (Sari dan Abundanti, 2016).

Dana pihak ketiga (DPK) merupakan sumber dana terbesar yang paling diandalkan oleh bank (Dendawijaya, 2005;84). Sumber dana dari masyarakat (DPK) ini di samping mudah untuk mencarinya juga tersedia banyak di masyarakat kemudian persyaratan untuk mencarinya juga tidak sulit (Kasmir, 2005:64). Kegiatan bank setelah menghimpun dana dari masyarakat luas adalah menyalurkan kembali dana tersebut kepada masyarakat yang membutuhkannya, dalam bentuk pinjaman atau lebih dikenal dengan kredit (Kasmir, 2011:65). Kredit yang disalurkan bank kepada masyarakat akan dapat meningkatkan taraf hidup masyarakat karena kredit tersebut dapat digunakan untuk melakukan investasi serta keperluan konsumsi. DPK memiliki kontribusi terbesar dari beberapa sumber dana sehingga jumlah DPK yang berhasil dihimpun oleh suatu bank akan mempengaruhi kemampuannya dalam menyalurkan kredit (Kasmir, 2011:25).

Non Perfoming Loan (NPL) adalah rasio yang digunakan untuk mengukur jumlah kredit bermasalah, apakah termasuk kredit yang diragukan, kurang lancar, atau macet terhadap total kredit yang disalurkan oleh bank. Dengan semakin tingginya rasio NPL mencerminkan bahwa semakin banyaknya jumlah kredit macet yang terdapat pada perusahaan, sehingga dapat mempengaruhi tingkat kesehatan perusahaan yang akhirnya dapat menurunkan jumlah pendapatan yang mampu diterima oleh perusahaan, baik penerimaan atas pengembalian pinjaman maupun penerimaan bunga atas pinjaman. Perusahaan dengan tingkat kredit macet yang bermasalah dapat menghambat perputaran uang di dalam perusahaan perbankan, sehingga perusahaan akan kesulitan untuk menyalurkan kembali dananya kepada pihak lain di samping dapat meningkatkan risiko bagi perbankan sendiri (Barus dan Lu, 2013).

Loan to Deposit Ratio (LDR) adalah rasio yang digunakan untuk mengukur hubungan antara seluruh jumlah kredit yang diberikan bank terhadap dana yang dapat 
diperoleh dari pihak ketiga, baik berupa tabungan, giro, dan deposito. Semakin tingginya rasio LDR mencerminkan bahwa sejumlah kredit yang diberikan oleh pihak perbankan semakin banyak, sehingga akan meningkatkan jumlah pendapatan bagi pihak bank atas penerimaan dari bunga pinjaman. Dengan semakin tinggi rasio LDR, maka perusahaan akan memperoleh tambahan dana lebih dari masyrakat yang akhirnya dapat disalurkan kembali kepada pihak yang mebutuhkan (Barus dan Lu, 2013).

Suku bunga kredit merupakan bunga yang dibebankan kepada para peminjam atau harga jual yang harus dibayar oleh nasabah peminjam kepada pihak bank (Kasmir, 2004:152). Menurut Liewellyu dan Hefferman (Yusuf, 2009) hubungan jumlah kredit yang disalurkan dengan tingkat suku bunga mempunyai hubungan yang negatif, yang bermakna bahwa semakin rendah tingkat suku bunga maka semakin besar jumlah kredit yang disalurkan. Suku bunga kredit ditentukan oleh tiga komponen, yaitu Cost of Fund, Overhead Cost, dan Spread Profit (Sinarwati dkk, 2015).

Berdasarkan uraian latar belakang masalah tersebut, maka judul pada penelitian ini adalah "PENGARUH DPK, NPL, LDR DAN SUKU BUNGA KREDIT TERHADAP PENYALURAN KREDIT UMKM PADA BANK PERKREDITAN RAKYAT(BPR) DI KOTA SEMARANG',

\section{Masalah Penelitian}

Berdasarkan latar belakang yang dikemukakan diatas, maka rumusan masalah dalam penelitisn ini adalah :

1. Apakah terdapat pengaruh antara Dana Pihak Ketiga terhadap penyaluran kredit UMKM di BPR sekota Semarang?

2. Apakah terdapat pengaruh antara Non Performing Loan terhadap penyaluran kredit UMKM di BPR sekota Semarang?

3. Apakah terdapat pengaruh antara Loan to Deposit Ratio terhadap penyaluran kredit UMKM di BPR sekota Semarang?

4. Apakah terdapat pengaruh antara Suku Bunga Kredit terhadap penyaluran kredit UMKM di BPR sekota Semarang? 


\section{Teori Penawaran Uang}

Bank berfungsi sebagai perantara dari pihak kelebihan dana dan pihak yang kekurangan dana. Bank menerima simpanan dana pihak ketiga dari pihak kelebihan dana dan memberikan penawaran kredit bagi pihak yang kekurangan dana dalam bentuk kredit investasi, kredit modal kerja, dan kredit konsumsi. Penawaran kredit ini dapat diartikan sebagai penawaran uang kepada masyarakat yang pihak yang kekurangan dana. Penawaran uang yang dilakukan oleh bank bergantung permintaan yang dilakukan oleh debitur. Permintaan uang dipengaruhi pula oleh suku bunga bank. Semakin rendah suku bunga pinjaman maka kecenderungan permintaan uang akan naik. Sedangkan penawaran uang yang dilakukan oleh bank mengikuti permintaan uang atau kebutuhan yang diminta oleh debitur ( Galih, 2011).

Pengaruh antara Dana Pihak Ketiga (DPK) terhadap penyaluran kredit UMKM

Dalam UU No.10 tahun 1998 dikatakan bahwa "bank adalah badan usaha yang menghimpun dana dari masyarakat dalam bentuk simpanan dan menyalurkannya kepada masyarakat dalam bentuk kredit dan atau bentuk-bentuk lainnya, dalam rangka meningkatkan taraf hidup masyarakat banyak". Dengan demikian, bank merupakan bagian dari lembaga keuangan yang memiliki fungsi intermediasi yaitu menghimpun dana dari masyarakat yang kelebihan dana dan menyalurkan dana yang dihimpunnya kepada masyarakat yang kekurangan dana (Abdullah, 2004:17). Oleh karena itu semakin besar dana pihak ketiga yang dihimpun dari pihak ketiga, maka peran bank untuk meyalurkan dana dari pihak ketiga untuk dikembalikan lagi ke pihak yang kekurangan dana melalui pemberian kredit juga dapat semakin meningkat (Galih, 2011).

Kajian empiris yang pernah dilakukan peneliti terdahulu yang sejalan dengan kajian teoritis adalah penelitian yang dilakukan oleh Rustariyuni dan Putra (2015) yang menyatakan bahwa DPK berpengaruh positif terhadap penyaluran kredit perbankan. Hal serupa dikemukakan juga oleh Sari (2013), Roring (2013) dan Purba dkk.(2016) yang menyatakan bahwa DPK berpengaruh positif terhadap penyaluran kredit, maka dirumuskan hipotesis pertama sebagai berikut.

$\mathrm{H}_{1}$ : Dana Pihak Ketiga (DPK) berpengaruh positif terhadap jumlah penyaluran kredit UMKM. 
Pengaruh antara Non Performing Loan (NPL) terhadap penyaluran kredit UMKM

Non Performing Loan (NPL) adalah rasio yang digunakan untuk mengukur jumlah kredit yang bermasalah, meliputi kredit kurang lancar, kredit diragukan, atau kredit macet terhadap jumlah kredit yang disalurkan oleh bank. Semakin tinggi tingkat kredit macet maka semakin buruk pula kualitas aset yang dimiliki bank. Oleh karena itu, bank harus berhati-hati dalam menyalurkan kredit ke masyarakat yang membutuhkan dana. Namun demikian, apabila semakin rendah tingkat kredit macet yang dialami suatu bank, maka jumlah kredit yang disalurkan akan semakin besar.

Sejalan dengan kajian teoritis, hasil penelitian yang dilakukan oleh Arianti dkk (2016), Putra dan Wirathi (2014) menemukan bahwa NPL berpengaruh negatif terhadap penyaluran kredit, maka dirumuskan hipotesis kedua sebagai berikut.

$\mathrm{H}_{2}$ : Non Performing Loan (NPL) berpengaruh negatif terhadap jumlah penyaluran kredit UMKM.

Pengaruh antara Loan to Deposit Ratio (LDR) terhadap penyaluran kredit UMKM

Menurut Riyadi (dalam Galih, 2011), LDR dapat dijadikan tolok ukur kinerja lembaga intermediasi yaitu lembaga yang menghubungkan antara pihak yang kelebihan dana (unit surplus of funds) dengan pihak yang membutuhkan dana (unit deficit of funds). Loan to Deposit Ratio adalah rasio antara seluruh jumlah kredit yang diberikan bank dengan dana yang diterima oleh bank. LDR tersebut menyatakan seberapa jauh kemampuan bank dalam membayar kembali penarikan dana yang dilakukan oleh deposan dengan mengandalkan kredit sebagai sumber likuiditasnya kepada debitur. Semakin tinggi Loan to deposit ratio maka kemampuan kredit yang telah disalurkan oleh bank juga semakin tinggi guna membayar kewajiban jangka pendeknya seperti membayar kembali pencairan dana deposan dari kreditur, bunga yang seharusnya diberikan, dan memenuhi permintaan kredit oleh debitur.

Sejalan dengan kajian teoritis, menurut penelitian yang dilakukan oleh Putra dan Wirathi(2014) menemukan bahwa LDR berpengaruh positif terhadap penyaluran kredit. Pernyataan tersebut didukung oleh Purba dkk (2016) yang menyatakan bahwa LDR berpengaruh positif terhadap penyaluran kredit, maka dapat dirumuskan hipotesis ketiga adalah sebagai berikut.

$\mathrm{H}_{3}$ : Loan to Deposit Ratio berpengaruh positif terhadap jumlah penyaluran kredit UMKM. 
Pengaruh antara Suku Bunga Kredit terhadap penyaluran kredit UMKM

Tingkat suku bunga kredit perbankan merupakan biaya oppurtunitas dalam pembentukan investasi oleh sektor bisnis, sehingga peningkatan tingkat bunga kredit perbankan akan menurunkan tingkat investasi dan kemudian menurunkan pertumbuhan ekonomi (Siregar, 2006).

Sejalan dengan kajian teoritis, menurut penelitian yang dilakukan oleh Irma (2011), Kaunang (2013), dan Roring (2013) yang menyatakan bahwa Suku Bunga Kredit berpengaruh negatif terhadap penyaluran kredit, maka dapat dirumuskan hipotesis keempat adalah sebagai berikut.

$\mathrm{H}_{4}$ : Suku bunga kredit berpengaruh negatif terhadap jumlah penyaluran kredit.

\section{Metodologi}

Metode analisis data yang digunakan dalam penelitian ini adalah metode analisis kuantitatif. Analisis kuantitatif menggunakan angka-angka, perhitungan statistik untuk menganalisis hipotesis, dan beberapa alat analisis lainnya. Analisis kuantitatif dengan mengumpulkan data-data yang kemudian diolah menggunakan SPSS (Statistical Package for Sosial Science) yang dihasilkan dalam bentuk tabel, grafik serta kesimpulan yang berfungsi untuk mengambil keputusan hasil analisis.

\section{Variabel Dependen Penyaluran Kredit UMKM}

Variabel dependen pada penelitian ini adalah jumlah penyaluran kredit UMKM. Kredit merupakan penyediaan uang ataupun tagihan, berdasarkan kesepakatan pinjam meminjam antara debitur dan kreditur, dimana pihak debitur diwajibkan untuk membayar hutangnya setelah jangka waktu tertentu beserta dengan bunga yang dikenakan. Jumlah kredit akan di Ln pada pengolahan data sebab data jumlah kredit, selisih data tiap perbankan terlalu besar antara perusahaan perbankan sehingga untuk menghindari distribusi data yang tidak normal digunakan Ln. Oleh karena itu jumlah kredit yang disalurkan dihitung dengan rumus sebagai berikut:

Kredit yang disalurkan $=$ Ln (jumlah kredit yang disalurkan) 
Variabel Independen

a. Dana Pihak Ketiga (DPK)

Dana pihak ketiga merupakan dana berupa simpanan dari masyarakat. BPR menerima simpanan dana pihak ketiga dalam bentuk tabungan dan deposito. Jumlah dana pihak ketiga akan di Ln pada pengolahan data sebab data dana pihak ketiga, selisih data tiap perbankan terlalu besar antara perusahaan perbankan sehingga untuk menghindari distribusi data yang tidak normal digunakan Ln. Sehingga pengukuran untuk variabel Dana Pihak Ketiga (DPK) dapat dirumuskan sebagai berikut:

DPK $=$ Ln (Tabungan + Deposito)

\section{b. Non Performing Loan (NPL)}

Non performing loan adalah rasio antara kredit bermasalah dengan kredit yang disalurkan. Rasio ini menunjukkan kemampuan manajemen bank dalam mengelola kredit bermasalah yang diberikan oleh bank. Kredit bermasalah adalah kredit dengan kualitas kurang lancar, diragukan, dan macet. Rasio NPL dapat dirumuskan sebagai berikut:

$$
\mathrm{NPL}=\frac{\text { Kredit Bermasalah }}{\text { Total Kredit }} \times 100 \%
$$

\section{c. Loan to Deposit Ratio (LDR)}

Loan to deposit ratio merupakan rasio untuk mengukur komposisi jumlah kredit yang diberikan dibandingkan dengan jumlah dana masyarakat dan modal sendiri yang digunakan sehingga dapat diketahui kemampuan bank membayar kewajiban jangka pendeknya. Rasio LDR dapat dirumuskan sebagai berikut :

$$
\mathrm{LDR}=\frac{\text { Jumlah Kredit Yang Diberikan }}{\text { Dana Masyarakat }+ \text { Modal }} \times 100 \%
$$

\section{d. Suku Bunga Kredit}

Suku Bunga Kredit merupakan bunga yang dibebankan kepada para peminjam atau harga jual yang harus dibayar oleh nasabah peminjam kepada pihak bank (Kasmir, 2004:152). Rasio Suku Bunga Kredit dirumuskan sebagai berikut :

Suku Bunga Kredit $=\mathrm{COF}+\mathrm{OHC}+\mathrm{SP}$

Dimana :

$$
\begin{aligned}
& \mathrm{COF}=\text { Cost of Fund } \\
& \mathrm{OHC}=\text { Overhead Cost } \\
& \mathrm{SP}=\text { Spread Profit }
\end{aligned}
$$




\section{Pembahasan}

Statistik Deskriptif

Tabel 1. Statistik Deskriptif

\begin{tabular}{lcclll}
\hline & & & & & \\
& $\mathrm{N}$ & \multicolumn{1}{c}{ Min } & \multicolumn{1}{c}{ Max } & \multicolumn{1}{c}{ Mean } & Std deviation \\
\hline KREDIT & 64 & 5592570.00 & 353548408.00 & 73750285.48 & 86359084.38 \\
DPK & 64 & 5347858.00 & 422606876.00 & 80806983.77 & 101505349.94 \\
NPL & 64 & 1.2575 & 40.6701 & 8.4065 & 6.7565 \\
LDR & 64 & 30.9560 & 135.0123 & 85.6753 & 18.0960 \\
SBK & 64 & 10.9628 & 20.7653 & 15.2029 & 1.9443 \\
N (Listwise) & 64 & & & &
\end{tabular}

Sumber : Data sekunder diolah, 2017

Berdasarkan tabel 1 maka dapat dijelaskan statistik deskriptif data penelitian sebagai berikut :

1. Jumlah kredit menunjukkan jumlah dana yang dikeluarkan oleh bank untuk menyalurkan kredit kepada pihak lain. Kredit dari BPR sampel menunjukkan rata-rata (mean) sebesar $\mathrm{Rp}$ 73.750.285,48. Nilai standar deviasi (standard deviation) kredit adalah sebesar Rp 86.359.084,38. Artinya standar deviasi lebih kecil dari mean yaitu Rp 86.359.084,38 < Rp 73.750.285,48 sehingga penyimpangan data yang terjadi rendah maka penyebaran datanya bersifat normal. Jumlah kredit terendah adalah sebesar Rp 5.592.570 yang diperoleh BPR Estetika Artha Guna pada tahun 2014, sedangkan jumlah kredit tertinggi adalah sebesar Rp 353.548.408 yang diperoleh BPR Gunung Rizki Pusaka Utama pada tahun 2016.

2. Dana Pihak Ketiga (DPK) menunjukkan jumlah dana dari pihak lain yang berasal dari deposito dan tabungan. Diketahui bahwa variabel DPK memiliki nilai minimum adalah sebesar Rp 5.347.858 yang diperoleh BPR Estetika Artha Guna pada tahun 2013, artinya bank tersebut pada tahun 2013 tidak maksimal dalam menjalankan kegiatan operasional bank karena DPK merupakan sumber dana terbesar dalam melakukan kegiatan operasional bank. Sedangkan nilai maksimum adalah sebesar Rp 422.606.876 yang diperoleh BPR Gunung Rizki Pusaka Utama pada tahun 2016, artinya bahwa dengan besarnya DPK mampu melakukan pembiayaan dan pengalokasian dana kepada nasabahnya yang termasuk bagian aktiva atau aset yang digunakan dalam memperoleh keuntungan. Sementara nilai standar deviasi (standard deviation) diperoleh sebesar Rp 101.505.349,94 dan nilai rata-rata (mean) sebesar Rp 80.806.983,77. Standar deviasi lebih besar dari mean yaitu Rp 101.505.349,94>Rp 80.806.983,77, hal ini menunjukkan bahwa data yang digunakan sebagai variabel DPK mempunyai sebaran besar, sehingga simpangan data pada variabel dana pihak ketiga ini dapat dikatakan kurang baik. 
3. Non Performing Loan (NPL) mencerminkan rasio kredit yang kurang dapat tertagih. Rasio ini dihitung dengan membagi total kredit bermasalah dengan total kredit yang dikeluarkan bank. Diketahui bahwa variabel NPL memiliki nilai maksimum adalah sebesar 40,6701\% yang diperoleh BPR Artha Mutiara pada tahun 2016, sedangkan nilai minimum NPL adalah sebesar 1,2575\% yang diperoleh BPR Weleri Makmur pada tahun 2013.Rata-rata NPL selama periode penelitian tahun 2013-2016 adalah sebesar 8,4065\%. Hal ini berarti bahwa besarnya rata-rata kredit bermasalah yang dimiliki bank adalah mencapai $8,4065 \%$ dari seluruh kredit yang diberikan BPR. Sementara nilai standar deviasi (standard deviation) adalah sebesar 6,7565\%.

4. Loan to Deposit Ratio (LDR) mencerminkan rasio antara kredit yang diberikan oleh bank kepada nasabahnya dibanding dengan dana pihak ketiga yang masuk atau yang terkumpul dari masyarakat. Diketahui bahwa nilai LDR memiliki nilai minimum adalah sebesar $30.9560 \%$ yang diperoleh BPR Artha Mutiara pada tahun 2016, sedangkan nilai maksimum adalah sebesar 135,0123\% yang diperoleh BPR Arto Moro tahun 2016. Sementara nilai rata-rata (mean) LDR adalah sebesar Rp. 85,6725\%. Hal ini berarti bahwa kredit yang dikeluarkan oleh BPR sampel mencapai 85,6725\% dibanding dengan deposit atau dana yang dihimpun dari masyarakat, sedangkan standar deviasi (standard deviation) adalah sebesar 18,0960\%.

5. Suku Bunga Kredit diukur dengan pendapatan bunga terhadap beban bunga dan biaya yang ditanggung bank. Variabel Suku Bunga Kredit menunjukkan rata-rata (mean) adalah sebesar $15.2029 \%$, sementara nilai standar deviasi (standard deviation) diperoleh sebesar $1.9443 \%$. Nilai minimum suku bunga kredit adalah sebesar $10.9628 \%$ yang diperoleh BPR Arto Moro pada tahun 2016, sedangkan nilai maksimum suku bunga kredit adalah sebesar $20.7653 \%$ yang diperoleh BPR Gunung Kawi pada tahun 2014.

Regresi Linier Betganda

Tabel 2. Hasil Uji Regresi Linier Berganda

\begin{tabular}{lcc}
\hline \multirow{2}{*}{ Model } & \multicolumn{2}{c}{ Unstandardized Coefficient } \\
\cline { 2 - 3 } & $\mathrm{B}$ & Std. Error \\
\hline 1. (Constant) & .581 & .197 \\
LnDPK & .925 & .008 \\
NPL & -.003 & .002 \\
LDR & .009 & .001 \\
SBK & -.002 & .005 \\
\hline
\end{tabular}

Dari tabel di atas maka diperoleh persamaan regresi linier berganda adalah sebagai berikut:

LnKREDIT $=0,581+0,925 \mathrm{LnDPK}-0,003 \mathrm{NPL}+$ 0,009 LDR $-0,002$ BUNGA

Berdasarkan persamaan regresi linier berganda diatas diperoleh nilai konstanta adalah sebesar 0,581. Angka tersebut menunjukkan tingkat penyaluran kredit UMKM yang diperoleh dari 
DPK, NPL, LDR dan SBK. Koefisien regresi LnDPK sebesar (+) 0.925, koefisien tersebut mengindikasikan adanya dampak positif antara variabel DPK terhadap penyaluran kredit UMKM. Koefisien regresi NPL sebesar (-) 0.003, koefisien tersebut mengindikasikan adanya dampak negatif antara variabel NPL terhadap penyaluran kredit UMKM. Koefisien regresi LDR sebesar (+) 0.009, koefisien tersebut mengindikasikan adanya dampak positif antara variabel LDR terhadap penyaluran kredit UMKM, dan koefisien regresi SBK sebesar (-) 0.002, koefisien tersebut mengindikasikan adanya dampak negatif antara variabel SBK terhadap penyaluran kredit UMKM.

Berdasarkan koefisien beta regresi pada tabel diatas dapat disimpulkan bahwa variabel DPK memiliki pengaruh yang paling besar terhadap penyaluran kredit UMKM dengan nilai koefisien beta regresi sebesar (+) 0.925, diikuti variabel LDR, NPL dan SBK dengan nilai beta regresi berturut-turut sebesar (+) 0,009, (-) 0.003 dan (-) 0.002 .

Pengujian Hipotesis

Koefisien determinasi $\left(\mathrm{R}^{2}\right)$

Tabel 3. Koefisien Determinasi

\begin{tabular}{cccc}
\hline & $\mathrm{R}$ & $\mathrm{R}$ Square & $\begin{array}{c}\text { Adjusted } \mathrm{R} \\
\text { Square }\end{array}$ \\
\hline 1 & $.998^{\mathrm{a}}$ & .996 & .996 \\
\hline
\end{tabular}

Pada tabel 3 nilai $\mathrm{R}^{2}$ sebesar 0,996>0,05. Hal ini menunjukkan bahwa hubungan antara variabel independen dengan variabel dependen adalah kuat, dan nilai adjusted $\mathrm{R}^{2}$ sebesar 0,996 . Hal ini menunjukkan bahwa 99,6\% variabel dependen penyaluran kredit UMKM dapat dijelaskan oleh variabel independen DPK, NPL, LDR, dan Suku Bunga Kredit, sedangkan sisanya 0,4\% dipengaruhi oleh variabel lain yang tidak dimasukkan dalam penelitian ini.

Uji Signifikan Simultan (Uji Statistik F)

\begin{tabular}{cccr}
\multicolumn{3}{c}{ Tabel 4. Uji F } \\
\hline & Model & F & Sig. \\
\hline 1 & Regresion & 4142.652 & .000 \\
& $\begin{array}{l}\text { Residual } \\
\text { Total }\end{array}$ & & a \\
\hline
\end{tabular}

Pada tabel 4 diperoleh nilai $\mathrm{F}$ sebesar 4142,652 dan sig 0,000 atau kurang dari 0,05, maka dapat disimpulkan bahwa variabel independen DPK, NPL, LDR, dan Suku Bunga Kredit secara bersama-sama atau simultan berpengaruh signifikan terhadap kredit yang diberikan BPR. 


\section{Uji t}

Tabel 5. Uji t

\begin{tabular}{lll}
\hline Model & \multicolumn{1}{c}{$\mathrm{t}$} & \multicolumn{1}{c}{ sig } \\
\hline (Constant) & 2.942 & .005 \\
LnDPK & 119.930 & .000 \\
NPL & -1.818 & .074 \\
LDR & 15.616 & .000 \\
SBK & -.426 & .672 \\
\hline
\end{tabular}

Berdasarkan hasil pengujian statistik t pada Tabel 5 menunjukkan bahwa:

a. Pengaruh Dana Pihak Ketiga (DPK) terhadap penyaluran kredit UMKM

Pengujian hipotesis nilai koefisien variabel Dana Pihak Ketiga (DPK) diperoleh nilai t sebesar 119,930 dan nilai signifikansi sebesar 0,000. Hal ini menunjukkan bahwa taraf signifikansi $0,000 \leq$ 0,05 , sehingga dengan kata lain mampu menolak $\mathrm{H}_{0}$. Dengan demikian $\mathrm{H}_{1}$ yang menyatakan bahwa Dana Pihak Ketiga (DPK) berpengaruh positif terhadap penyaluran kredit UMKM diterima

Hasil penelitian ini mengindikasikan bahwa peningkatan atau penurunan DPK selama periode penelitian mempengaruhi penyaluran kredit secara signifikan. Semakin tinggi DPK yang berhasil dihimpun oleh bank, akan mendorong peningkatan jumlah kredit yang disalurkan, demikian pula sebaliknya. DPK merupakan variabel yang memiliki pengaruh paling besar terhadap penyaluran kredit perbankan. Hal ini dikarenakan DPK merupakan sumber pendanaan yang utama.

\section{b. Pengaruh Non Performing Loan (NPL) terhadap penyaluran kredit UMKM}

Pengujian hipotesis nilai koefisien variabel Non Performing Loan (NPL) diperoleh nilai $\mathrm{t}$ sebesar $-1,818$ dan nilai signifikansi sebesar 0,074. Hal ini menunjukkan bahwa taraf signifikansi 0,074 > 0,05, sehingga dengan kata lain tidak mampu menolak $\mathrm{H}_{0}$. Dengan demikian $\mathrm{H}_{2}$ yang menyatakan bahwa Non Performing Loan (NPL) berpengaruh negatif terhadap penyaluran kredit UMKM tidak diterima.

Hasil penelitian ini mengindikasikan bahwa NPL memiliki pengaruh negatif yang signifikan terhadap penyaluran kredit UMKM. Hal ini berarti bahwa berkaitan dengan kualitas financing atau penyaluran kredit yang diberikan oleh sebuah bank. Dalam hal ini karena penyaluran kredit merupakan sumber utama pendapatan bank. Di sisi lain adanya kredit macet setidaknya akan dapat mengganggu perputaran modal kerja dari bank. Maka manakala bank memiliki jumlah kredit macet yang tinggi, maka bank akan berusaha terlebih dahulu mengevaluasi kinerja dengan sementara menghentikan penyaluran kreditnya hingga kredit macet berkurang. 


\section{c. Pengaruh Loan to Deposit Ratio (LDR) terhadap penyaluran kredit UMKM}

Hasil dari pengujian hipotesis nilai koefisien variabel Loan to Deposit Ratio (LDR)diperoleh nilai t sebesar 15,616 dan nilai signifikansi sebesar 0,000. Hal ini menunjukkan bahwa taraf signifikansi $0,000 \leq 0,05$, sehingga dengan kata lain mampu menolak $\mathrm{H}_{0}$. Dengan demikian $\mathrm{H}_{3}$ yang menyatakan bahwa Loan to Deposit Ratio (LDR) berpengaruh positif terhadap penyaluran kredit UMKM diterima.

Alasannya adalah bahwa LDR merupakan jenis rasio likuiditas bank.Bank yang memiliki penyaluran kredit yang besar menunjukkan penyaluran kredit yang besar. Namun demikian penyaluran kredit yang besar tanpa diimbangi dengan pemasukan atau penarikan dana dari masyarakat berupa tabungan atau deposito juga akan membahayakan bank. Hal ini menunjukkan pengaruh pada kemampuan kredit pada suatu bank, karena semakin tinggi LDR maka kemampuan kredit yang telah disalurkan oleh bank juga semakin tinggi dalam memenuhi kewajiban jangka pendeknya. Sebaliknya semakin rendah LDR maka kemampuan kredit yang telah disalurkan oleh bank juga semakin rendah dalam memenuhi kewajiban jangka pendeknya.

\section{d. Pengaruh Suku Bunga Kredit terhadap penyaluran kredit UMKM}

Hasil pengujian hipotesis nilai koefisien variabel Suku Bunga Kredit diperoleh nilai t sebesar -0,426 dan nilai signifikansi sebesar 0,672. Hal ini menunjukkan bahwa taraf signifikansi 0,672 > 0,05, sehingga dengan kata lain tidak mampu menolak $\mathrm{H}_{0}$. Dengan demikian $\mathrm{H}_{4}$ menyatakan bahwa Suku Bunga Kredit berpengaruh negatif terhadap penyaluran kredit UMKM tidak diterima.

Kondisi ini menggambarkan bahwa kondisi suku bunga kredit yang lebih tinggi tidak berimbas kepada penerimaan kredit yang diberikan oleh BPR. Hal ini karena suku bunga yang lebih tinggi memiliki efek yang berlawanan sehingga kredit pada beberapa bank tidak terpengaruh secara signifikan.

\section{Kesimpulan}

Berdasarkan hasil analisis yang dilakukan pada BPR di Kota Semarang periode tahun 20132016, maka dapat diambil kesimpulan sebagai berikut:

a. Dalam pengujian hipotesis pertama, diketahui bahwa Dana Pihak Ketiga (DPK) berpengaruh positif yang signifikan terhadap penyaluran kredit UMKM Bank Perkreditan Rakyat. Semakin tinggi DPK, maka akan tinggi pula kredit yang disalurkan, begitu juga sebaliknya. DPK berperan penting dalam mendorong jumlah kredit yang disalurkan oleh bank. DPK merupakan variabel yang memiliki pengaruh paling besar terhadap penyaluran kredit perbankan, karena DPK merupakan sumber pendanaan yang utama. 
b. Dalam pengujian hipotesis kedua, diketahui bahwa Non Performing Loan (NPL) berpengaruh negatif yang signifikan terhadap penyaluran Kredit UMKM Bank Perkreditan Rakyat. Hasil penelitian ini mengindikasikan bahwa semakin tinggi tingkat NPL, maka semakin besar pula risiko kredit yang disalurkan. Bank yang memiliki jumlah kredit macet tinggi, maka bank akan berusaha terlebih dahulu mengevaluasi kinerja dengan sementara menghentikan penyaluran kreditnya hingga kredit macet berkurang.

c. Dalam penelitian hipotesis ketiga, diketahui bahwa Loan to Deposit Ratio (LDR) berpengaruh positif yang signifikan terhadap penyaluran kredit UMKM Bank Perkreditan Rakyat. Semakin tinggi LDR pada suatu bank akan mengakibatkan semakin rendahnya likuiditas bank tersebut karena jumlah dana yang diperlukan untuk membiayai kredit menjadi semakin besar, sebaliknya semakin rendah LDR maka akan mengakibatkan semakin tingginya likuiditas bank yang bersangkutan. Hal ini menunjukkan pengaruh pada kemampuan kredit pada suatu bank, karena semakin tinggi LDR maka kemampuan kredit yang telah disalurkan oleh bank juga semakin tinggi dalam memenuhi kewajiban jangka pendeknya. Sebaliknya semakin rendah LDR maka kemampuan kredit yang disalurkan oleh bank juga semakin rendah dalam memenuhi kewajiban jangka pendeknya.

d. Dalam pengujian hipotesis keempat, diketahui bahwa Suku Bunga Kredit (SBK) berpengaruh negatif yang signifikan terhadap penyaluran kredit UMKM Bank Perkreditan Rakyat. Hal ini berarti bahwa kondisi makro ekonomi suku bunga kredit yang lebih besar, dalam hal ini tidak menghasilkan penyaluran kredit yang lebih kecil oleh BPR. Kondisi ini menggambarkan bahwa suku bunga kredit yang lebih tinggi tidak berimbas kepada kredit yang disalurkan oleh BPR.

\section{Daftar Pustaka}

Abdullah, Faisal. 2004. Manajemen Perbankan: Tehnik Analisis Kinerja Keuangan Bank, Universitas Muhammadyah, Malang.

Anggraini Dewi, dan Hakim. 2013. Peranan Kredit Usaha Rakyat (KUR) Bagi Pengembangan UMKM Di Kota Medan (Studi Kasus Bank BRI). Vol. 1, No. 3 Februari 2013. Jurnal Ekonomi dan Keuangan.

Barus, Andreani Carolin., Marya Lu. 2013. Pengaruh Spread Tingkat Suku Bunga Dan Rasio Keuangan Terhadap Penyaluran Kredit UMKM Pada Bank Umum di Indonesia. Jurnal Wira Ekonomi Mikroskil. Volume 3, Nomor 01, April 2013. Medan. STIE Mikroskil.

Dendawijaya, Lukman. 2005. Manajemen Perbankan. Jakarta: Ghalia Indonesia.

Galih, T.A. 2011. Pengaruh Dana Pihak Ketiga, Capital Adequasy Ratio, Non Performing Loan, Return on Assets, dan Loan to Deposit Ratio Terhadap Jumlah Penyaluran Kredit Pada Bank Di Indonesia (Studi Empiris: Bank Yang Terdaftar di BEI). Skripsi. Semarang: Universitas Diponegoro.

Kasmir. 2004. Bank dan Lembaga Keuangan Lainnya. Jakarta: PT Raja Grafindo Persada. 
Kasmir. 2005. Bank dan Lembaga Keuangan Lainnya. Jakarta: Rajawali PT Raja Grafindo Persada.

Kasmir. 2008. Dasar-dasar Perbankan: Sumber Dana Bank. Jakarta: PT Raja Grafindo Persada.

Kasmir. 2011. Analisis Laporan Keuangan. Jakarta: PT Raja Grafindo Persada.

Kaunang, Glently. 2013. Tingkat Suku Bunga Pinjaman Dan Kredit Macet Pengaruhnya Terhadap Permintaan Kredit UMKM Di Indonesia. Jurnal EMBA Vol. 1. No. 3 September 2013, Hal. 920-930. Manado: Fakultas Ekonomi dan Bisnis, Jurusan Ilmu Ekonomi Universitas Sam Ratulangi. ISSN: 2303-1174.

Paleni, Herman., dan Sheilla Aurora. 2016. Pengaruh Non Performing Loan (NPL) Dan Loan to Deposit Ratio (LDR) Terhadap Return On Asset (ROA) Pada PT BPR Sindang Binaharta Kota Lubuklinggau, Jurnal Adminika Volume 2. No. 2, JuliDesember 2016. Lubu Linggau: STIE Musi Rawas. ISSN: 2442-3343.

Purba, Novyanti Nora., dkk. 2016. Faktor-Faktor Yang Mempengaruhi Tingkat Penyaluran Kredit Pada BPR Konvensional Di Indonesia, Jurnal Aplikasi Bisnis dan Manajemen. Bogor: Institut Pertanian Bogor. E-ISSN: 2460-7819. Vol.2 No.2, Mei 2016.

Putra, I.G.A.N Bagus Grahadika., I.G.A.N Wirathi. 2014. Pengaruh LDR, BI Rate, CAR, NPL Terhadap Penyaluran Kredit UMKM Di Bank Umum Provinsi Bali Periode 2004.I-2013.IV, E-Jurnal EP Unud, 3(12): 603-612. Denpasar: Universitas Udayana. ISSN: 2303-0178

Roring, Gaby D.J. 2013. Analisis Determinan Penyaluran Kredit Oleh Bank Perkreditan Rakyat (BPR) Di Kota Manado, Jurnal EMBA. Manado: Universitas Sam Ratulangi. ISSN: 2303-1174. Vol.1 No.3 September 2013, Hal.1030-1040.

Rustariyani, Surya Dewi., I Gede Oggy Pratama Putra. 2015. Pengaruh DPK, BI Rate dan NPL Terhadap Penyaluran Kredit Modal Kerja Pada BPR Di Provinsi Bali Tahun 2009-2014. E-Jurnal EP Unud, 4(5): 451-464. Bali. ISSN: 2303-0178.

Sari, Greydi Normala. 2013. Faktor-Faktor Yang Mempengaruhi Penyaluran Kredit Bank Umum di Indonesia (Periode 2008-2012). Jurnal Ekonomi Manajemen, Bisnis, dan Akuntansi, 1(3): pp: 931-941.

Sari, Ni Made Junita., dan Nyoman Abundanti. 2016. Pengaruh DPK, ROA, Inflasi Dan Suku Bunga SBI Terhadap Penyaluran Kredit Pada Bank Umum, E-Jurnal Manajemen Unud, Vol. 5, no. 11, 2016: 7156-7184. Bali, Indonesia: Fakultas Ekonomi dan Bisnis Universitas Udayana. ISSN: 2302-8912.

Sinarwati, Ni Kadek., dkk. 2015. Analisis Pengaruh Tingkat Suku Bunga Kredit, Pertumbuhan Kredit, Loan To Deposit Ratio, dan BOPO Terhadap Profitabilitas LPD (Studi Kasus Pada lembaga Perkreditan Desa Se-Kecamatan Buleleng Periode 2011-2013). E-Journal Jurusan Akuntansi Program S1. Singaraja. Volume 3 No. 1.

Siregar, T. T. M. 2006. Analisis Faktor-Faktor Yang Mempengaruhi Permintaan Kredit Pada Bank Pemerintah di Sumatera Utara. USU Repository. 2007.

Yusuf, Mohammad. 2009. Faktor-Faktor Yang Mempengaruhi Permintaan Kredit Konsumtif Bank Pemerintah Di Sumatera Utara. Tesis. Medan: Pasca Sarjana Universitas Sumatera Utara. 